\title{
CREATIVITY AS A STIMULANT OF SOCIO-ECONOMIC DEVELOPMENT OF THE PODKARPACKIE VOIVODESHIP
}

\author{
Anna Mazurkiewicz, PhD; Katarzyna Szara, $\mathrm{PhD}^{2}$
}

Faculty of Economics, University of Rzeszów

\begin{abstract}
In social and economic development, significance is primarily attributed to endogenous resources. The local conditions should play a key role in it. One of the characteristic features of the region and at the same time a key one is human capital which conditions the occurrence of creative capital. In the paper, creativity - as a resource appropriate to people, a feature of the individual - its potential for creative achievements currently or in the future will be analysed through the prism of creative capital.

The aim of the article is to evaluate the conditions for the development of creative capital of the Podkarpackie municipalities in the context of their social and economic development. The evaluation will be made in regard to human resources. In order to achieve the goal of the study, the literature of the subject was analysed, numerical data published by the Central Statistical Office was used, and empirical studies were carried out in the offices of the Podkarpackie municipalities. The results of the conducted research showed that there are conditions favourable to the development of creative capital in the region. The majority of the inhabitants of the Podkarpackie Voivodeship municipalities saw the importance of creativity for the development of the commune.
\end{abstract}

Keywords: creativity, region, development

JEL codes: J24, O15, O18, P48, R11

\section{INTRODUCTION}

Development is a category that is ambiguous and interpreted in various contexts - above all in terms of changes taking place, both quantitative and qualitative ones (Stec et al., 2014). The development of the region is a consequence of qualitative changes and economic growth (Kosiedowski, 2001). It is connected with changes in production capacities and economic relations, which results in the improvement of production factors and an increase in the quantity and quality of goods and services. Economic development is also associated with social development, meaning 'a change in the social relations, structure of society, its preferences, social criteria and principles of activity, behaviour patterns, attitudes and awareness aimed at improving co-existence, cooperation of people and their appropriate participation in the effects of economic development' (Marciniak, 2005).

In social and economic development, an important role is attributed to endogenous resources. The local

${ }^{1}$ Corresponding author: al. Rejtana 16c, 35-001 Rzeszów, Poland, annam@ur.edu.pl, +4817 8721677

${ }^{2}$ Corresponding author: al. Rejtana 16c, 35-001 Rzeszów, Poland, 33ksz@wp.pl, +48 609987770 
conditions should play a key role - it is necessary to create and use local advantages taking into account knowledge, experience, skills and specializations, as well as links between particular entities (Ministerstwo Rozwoju Regionalnego, 2010). One of the characteristic features of the region, and at the same time a key one, is human capital, which favours, among others, generating new technologies, innovativeness of the economy, its ability to absorb new solutions, increase productivity, per capita income growth, political and community participation and social cohesion (OECD, 2001).

Human capital determines the existence of creative capital, interpreted as a resource appropriate to people who act and cooperate with each other using their creativity. Creative capital refers to the conditions (talent, technology, tolerance) that predestine a given area for development. At the same time, it is inseparable from the human factor (Szara, 2015). Through the prism of creative capital, creativity is analysed - as a resource appropriate to people, a characteristic of the individual - its potential for creative achievements at present or in the future, but not necessarily realized creativity (Nęcka, 2012).

Creativity is quite common in the population, it is a characteristic of children, adolescents and adults to the extent that they are characterized by an ability to ask themselves and the world important questions or wonder (Karwowski, 2009). Human creativity leads to different effects but the basic condition for obtaining certain results is to arouse it - despite the egalitarity of this feature, not every individual uses it.

The observations provided are the basis for stating that the creation of conditions for socio-economic development takes place at the local and regional level - strategic areas for economic development. Creativity should, therefore, be assigned an important role in socio-economic development (UNCTAD, 2008; Rindermann, Sailer and Thompson, 2009; Reid, Albert and Hopkins, 2010). The aim of the paper is to evaluate the conditions for the development of creative capital of the Podkarpackie municipalities in the context of their social and economic development. The evaluation will be made in regard to human resources. In order to achieve the goal of the study, the literature of the subject was analysed, the numerical data published by the Central Statistical Office (Local Data Bank) was used, and empirical studies were also carried out. The article emphasized the importance of creativity in economic and social life, the results of empirical research were presented and subjected to qualitative analysis.

\section{CREATIVITY IN THE LIFE OF SOCIETY}

The issue of creativity in regional development is the subject of interest for many entities, including, among others: local government authorities, nongovernmental organizations, entrepreneurs or representatives of science. The implementation of activities that exploit the potential of creativity can have a positive impact on regional development. Creativity fosters innovation - it supports the emergence of new, original and useful solutions, which are a response to the challenges of a dynamically changing environment, which in turn affects the region's development potential, is important for its competitiveness. The transformation of existing structures is, according to Schumpeter, the most important feature of the market and at the same time as a result of implementing innovation, a determinant of economic development (Towse, 2011). Innovation is the result of creativity (Florida, 2010).

The human work products resulting from the implementation of creative solutions become more competitive, enable to meet higher-order needs instead of providing exclusively functional benefits - they offer added value (Raszkowski, 2016). Creativity is one of the factors creating the quality of human capital, which may be more important for regional development than its number. The use of individual knowledge, creativity and talent contributes to many positive phenomena in the economy and society, especially to create innovation, a GDP growth, creation of new jobs, citizens' openness to new solutions and cooperation, through contribution to education - strengthening national and regional identity, and as a result, to improve the residents' quality of life. The results may be negative at the same time, in the form of, for example, of excessive consumption and waste, which affects the natural environment (Knop, 2015). 


\section{CHARACTERISTICS OF HUMAN CAPITAL OF THE PODKARPACKIE VOIVODESHIP - SELECTED ELEMENTS}

The Polish socio-economic space is characterized by strong diversification in the level of regional development. Taking into account the level of GDP, which is a measure reflecting the economic potential of a given region, the share of the Podkarpackie Voivodeship in the creation of Polish GDP amounted to 3.9\% (2016). Quoting from Woźniak, 'about the potential of each economy (...), and especially its quality is determined by the scale of investment in man, so human capital becomes to a certain extent a function of GDP per capita' (Woźniak, 2005), should be pointed to a weak position of the Podkarpackie Voivodeship compared to other regions of the country - GDP per capita was PLN 33,176, which is $70.9 \%$ of the average for the country. Such results put the voivodeship on the penultimate place among the others.

A more detailed analysis of the region's human capital is made taking into account the basic attributes of this capital, including among others (Gaczek and Komorowski, 2005): the structure of the population's age and the rate of burden on people of working age by people in pre-working and post-working age, occupational activity of the population, an employment rate, an education level, an occupational structure and population prosperity.

In the Podkarpackie Voivodeship, unfavourable changes in the structure in relations between particular age groups should be emphasized - from 2010 the percentage of post-working age people increased significantly (from 15.89 to $18.76 \%$ in 2016), while the share of people in pre-working age (from 20.25 to $18.37 \%$ ) and a slight decline in the share of people of working age (by about $1 \mathrm{pp}$ to $62.87 \%$ ). Taking into account demographic forecasts, this trend will deepen. Such a state means decreasing labour resources and, at the same time, the region's potential for creativity - the activity of professionally active people, at the same time affecting private life - achieving per- sonal goals, using the emerging opportunities. This means that there is a potential presence in this group of units with creative potential.

Education is a factor of crucial importance for the development of a creativity. It is assumed that the better educated population of the region is more creative (Podogrodzka, 2017). The population structure of the Podkarpackie Voivodship, regarding the education criterion ${ }^{3}$, was dominated by people with secondary education (general and vocational), accounting for $27.9 \%$ of the population. The size of this group increased in comparison with the results of the 2002 census (by 31.7 thousand people), while the share in the population structure remained at a similar level (27.6\% in 2002). The share of people with basic vocational education was also significant $(21.7 \%)$. People with higher education (at least bachelor, engineer, and qualified economist) constituted $14.5 \%$ of the population, which means a significant increase compared to the previous census - by more than $6 \mathrm{pp}$.

An addition to the previous considerations is information on the professional activity of the population - the value of this coefficient for people aged 15 and more in 2016 increased compared to the previous year and amounted to $55.9 \%$ compared to $54.2 \%$, which was significantly higher in the group of men than women (amounted to 64.9 and $47.4 \%$, respectively), but there were no differences with regard to the area of residence $(55.9 \%)$. The differences concerned the employment rate, which increased from 48 to $50.6 \%$, taking into account both the gender criterion (in 2016 it was $58.6 \%$ for men, $43 \%$ for women) and the place of residence $(51.4 \%$ in cities and $50.0 \%$ in rural areas). The place of residence is an important factor in the analysis of creativity, the quality of human capital. More favourable living conditions in terms of access to infrastructure, leisure activities are provided by cities. Also an access to information seems to be easier in these areas. The population structure due to the place of residence indicates the predominance of the agricultural population $(58.8 \%)$.

\footnotetext{
${ }^{3}$ Information on the level of education of the population was obtained from the 2011 National Population Census (Urząd Statystyczny Rzeszów, 2012).
} 
The presented information shows the unfavourable development of processes contributing to the creation of human capital, which are characterized by high development opportunities. The main reason is the systematic aging of the inhabitants of the voivodeship (an increase in the median value of the population's age from 36.5 years in 2010 to 39.1 years in 2016). Occupational activity of the population in the Podkarpackie Voivodeship is lower than the average in Poland, which places the region in the second half of the voivodeships. Therefore, it becomes important to stimulate and use the creativity of its inhabitants, which is the basis for the development of the creative capital of the region. An important factor supporting this process is the adequately high level of education of residents.

\section{MATERIALS AND METHODS}

In order to evaluate selected conditions for the development of the creative capital of the region, a full study was set up among all 160 offices of the Podkarpackie municipalities. These municipalities constitute $6 \%$ of all communes in Poland. The survey carried out using the CAWI method was preceded by a telephone contact informing about the research assumption and the request to complete the questionnaire. The questionnaire regarding the creative capital development in the municipality was completed in July-August 2015. In the offices, the questionnaire was filled in by three randomly selected employees, at various levels of the organizational structure. From the originally assumed population of 480 the researched, 453 questionnaires were returned $(94.4 \%)^{4}$.

The questionnaire consisted of 28 questions. It included questions regarding the respondents' assessment of the determinants of the development of creative capital in the commune in various areas - in reference to the 3T concept (talent, technology, tolerance). This work uses a part of the research related to the assessment of creativity of human resources in the context of the development of the commune. The use of selected questions was justified by specific needs resulting from the purpose of the study, as well as the requirements for the volume of the paper.

Respondents evaluated eight statements, assessed in a 5-point Likert scale, from 1 ('I totally disagree') to 5 ('I totally agree'), in which 3 meant a neutral position ('I have no opinion'). These statements were preceded by questions regarding the interpretation by the respondents of the concept of creativity as a characteristic, manifestations of creativity and the possibility of using creativity at work (the commune office).

\section{RESEARCH RESULTS}

The results of the conducted research regarding the assessment by the respondents of the commune's creative capital in the tolerance area are presented in Table 1. Table 2 presents the results of respondents' opinions on the importance of creativity for the development of the municipality.

Tolerance means the openness and favour of residents towards people of other races, nationalities, as well as those who choose different ways of life (Podogrodzka, 2017). Creating conditions conducive to the development of creative capital of the region requires offering solutions that meet the diverse needs of particular social groups, also related to lifestyle. Regions that value diversity and tolerance offer stimulating places with high level of cultural interplay (Florida, 2002).

The conducted research proves that according to the vast majority of respondents (almost 79\%), the community of the municipality is kind to visitors. A different opinion was less than $4 \%$ of respondents, the rest $(17.44 \%)$ did not have an opinion on this subject. More than half of the persons participating in the survey $(55.4 \%)$ positively assessed the tolerance of the municipality's inhabitants to national minorities, almost $12 \%$ assessed this issue negatively, while almost $1 / 3$ of the respondents did not evaluate the community in this respect. The condition of tolerance was more positively assessed in rural and urban-rural

\footnotetext{
${ }^{4}$ Six municipalities (Dynów, Gawłuszkowice, Nowa Szarzyna, Sokołów Małopolski, Strzyżów, and Żołynia) refused to participate in the study. The number of three questionnaires was not obtained from five municipalities.
} 
Proceedings of the 2018 International Scientific Conference 'Economic Sciences for Agribusiness and Rural Economy' No 2, Warsaw, 7-8 June 2018, pp. 287-293

Table 1. Evaluation of the creative capital of a commune in the area of tolerance

\begin{tabular}{|l|c|c|c|c|c|}
\hline \multirow{2}{*}{ Specification } & \multicolumn{5}{|c|}{ Likert scale } \\
\cline { 2 - 6 } & 1 & 2 & 3 & 4 & 5 \\
\cline { 2 - 6 } & \multicolumn{5}{|c|}{$\%$} \\
\hline $\begin{array}{l}\text { The commune community is kind to the people who come } \\
\text { here }\end{array}$ & 1.32 & 2.65 & 17.44 & 49.89 & 28.70 \\
\hline The commune community is tolerant to national minorities & 1.77 & 10.15 & 32.67 & 42.38 & 13.02 \\
\hline
\end{tabular}

Source: authors' own research based on study outcomes.

Table 2. Respondents' opinions regarding the impact of creativity on changes in the municipality

\begin{tabular}{|c|c|c|c|c|c|}
\hline \multirow{3}{*}{ Specification } & \multicolumn{5}{|c|}{ Likert scale } \\
\hline & 1 & 2 & 3 & 4 & 5 \\
\hline & \multicolumn{5}{|c|}{$\%$} \\
\hline People's creativity evokes changes in the commune & 3.97 & 8.39 & 13.25 & 42.38 & 32.01 \\
\hline $\begin{array}{l}\text { Creativity of people in the commune most often improves } \\
\text { their life situation }\end{array}$ & 3.53 & 10.15 & 20.53 & 45.70 & 20.09 \\
\hline Creativity determines innovation & 3.97 & 6.84 & 22.96 & 39.29 & 26.93 \\
\hline Creativity allows to develop human capital in the commune & 3.09 & 9.93 & 17.66 & 49.23 & 20.09 \\
\hline Creativity allows to develop social capital in the commune & 3.31 & 8.61 & 23.62 & 46.14 & 18.32 \\
\hline 'Using' creativity increases the attractiveness of the commune & 3.97 & 10.38 & 21.85 & 42.16 & 21.63 \\
\hline
\end{tabular}

Source: authors' own research based on study outcomes.

municipalities (55.76 and $56.99 \%$ respectively) than in urban ones (48.72\% of indications).

The respondents' opinions on the impact of creativity on changes in the municipality (Table 2 ) prove that most of them (almost 3/4) perceive the role of creativity in this area. A different opinion had more than $12 \%$ of respondents, and a little more did not have an opinion. Almost two-thirds of the surveyed participants confirmed that the creativity of people in the municipality most often improves their life situation. Almost $14 \%$ of them did not agree with this observation, and $1 / 5$ had no opinion. Similar opinions were presented by the respondents regarding the connection of innovativeness in the commune with creativity. About $70 \%$ of respondents were convinced that creativity allowed for the development of individual human capital in the municipality. As many as $13 \%$ commented negatively on the subject, $17.66 \%$ did not have an opinion. A slightly smaller percentage of positive answers concerned the belief about the impact of creativity on the development of social capital in the commune $(64.5 \%)$. In comparison with the previous answer, the percentage of negative responses was lower (almost 12\%). The remaining part of the respondents (almost 1/4) could not specify their opinion on the subject. The summary of the opinion on the importance of creativity for the development of the commune was the statement regarding the impact of using the potential of creativity on the attractiveness of the commune - a positive opinion on this issue 
was expressed by almost $64 \%$ of respondents, and over $14 \%$ - negative. The others represented a neutral position $(21.85 \%)$. It should be emphasized that in relation to each statement, the extreme answers ('I completely disagree' and 'I completely agree') were given by a smaller proportion of respondents assessing negatively and positively particular issues.

\section{CONCLUSIONS}

Creativity is an important asset for citizens in a knowledge-based economy - it determines innovation as a key factor in the economic and social development of the region and the country. Human capital is a carrier of the creative potential, at the same time the creativity of individuals determines the quality of this capital, which may turn out to be more significant for the development processes of the region than its size. Supporting individual, bottom-up creativity contributes to the improvement of the quality of human capital, also providing a valuable resource for the creative industries.

The current demographic situation in the Podkarpackie Voivodeship and trends in this respect should be assessed as unfavourable in the context of the state of human capital, as well as the basis for shaping creativity. This is evidenced by the rise of the median of the age and the average life expectancy of the population, which is the consequence of the aging of the inhabitants and, hence, the labour resources. This situation is reflected in the population structure, taking into account the criterion of economic age groups. At the same time, however, positive but slight changes should be positively assessed regarding an increase in the economic activity of the population and the level of employment. The level of measures was higher for men and people living in the countryside. In conclusion, the analysis of objective (statistical) data on human capital in the Podkarpackie region does not provide a positive assessment of the region compared to other voivodeships.

At the same time, there are conditions conducive to the development of creative capital in the region - an important factor supporting this development is a large proportion of people with higher education (at least bachelor degree), although lower than the national average (17\%). In addition, the majority of respondents pointed to the openness and friendliness of residents towards foreign visitors and national minorities. However, a large part of the community presents, in the opinion of respondents, a neutral position in the presented area, which concerns in particular tolerance towards national minorities.

Inhabitants are aware also of the importance of creativity for the development of the municipality, which is important for development processes. Most of them saw the importance of creativity for creating changes at the local level as well as for the residents. Among the respondents, however, there were also people who spoke negatively in the presented field. A large part of the respondents had no opinion on the impact of creativity on the lives of residents and improvement of the situation in their municipality.

Knowledge about the importance of creativity is not in itself sufficient for regional development. However, awareness of the potential benefits of perceiving creativity as a factor stimulating development processes, as well as ways to achieve these benefits, provides an incentive to take actions that will enable the use of available endogenous resources and, as a result, create advantages that form the basis of social and economic development. These advantages can be built, among others, on an educational offer developing human talents, supporting innovative solutions, developing creative industries. The obtained results of the conducted research prove that the Podkarpackie Voivodeship is a source of resources with creative potential, which can be used to stimulate the socioeconomic development of the region.

\section{REFERENCES}

1. Florida, R. (2002). The Rise of the Creative Class. Why cities without gays and rock banda are losing the economic development race. Washington Monthly, 11. Retrieved: www.washingtonmonthly.com/features/2001/0205.florida.html [Accessed 02.07.2018].

2. Florida, R. (2010). Narodziny klasy kreatywnej oraz jej wpływ na przeobrażenia w charakterze pracy, wypoczynku, społeczeństwa i życia codziennego [The birth of the creative class and its impact on transformations in the nature of work, leisure, society and everyday life]. Narodowe Centrum Kultury, Warszawa. 
3. Gaczek, W.M., Komorowski, J.W. (2005). Kapitał ludzki i społeczny regionu jako element rozwoju gospodarczego [Human and social capital of the region as an element of economic development]. In: Gaczek, W.M. (ed.) Innowacje w rozwoju region [Innovations in the development of the region]. Akademia Ekonomiczna w Poznaniu, Poznań, p. 53.

4. Karwowski, M. (2009). Klimat dla kreatywności. Koncepcje, metody, badania [A climate for creativity. Concepts, methods, research]. Difin, Warszawa.

5. Knop, L. (2015). Rozwój przemysłów kreatywnych w kontekście inteligentnych specjalizacji [Development of creative industries in the context of smart specializations]. In: Jelonek, D., Turek, T. (eds.) Kreowanie przedsiębiorczości. Perspektywa procesów i technologii informacyjnych [Creation of entrepreneurship. Perspective of processes and information technologies] Politechnika Częstochowska, Częstochowa, pp. 11-25.

6. Kosiedowski, W. (2001). Teoretyczne problemy rozwoju regionalnego [Theoretical problems of regional development]. In: Kosiedowski, W. (ed.) Zarządzanie rozwojem regionalnym i lokalnym [Management of regional and local development]. Dom Organizatora, Toruń, p. 28.

7. Marciniak, S. (ed.) (2005). Makro- i mikroekonomia. Podstawowe problemy [Macro- and microeconomics. The basic problems]. PWN, Warszawa.

8. Ministerstwo Rozwoju Regionalnego (2010). Krajowa Strategia Rozwoju Regionalnego 2010-2020: Regiony, Miasta, Obszary Wiejskie [National Strategy of Regional Development 2010-2020: Regions, Cities, Rural Areas]. Warszawa. Retrieved from: http://prawo.sejm. gov.pl/isap.nsf/download.xsp/WMP20110360423/O/ M20110423.pdf [Accessed 19.03.2018].

9. Nęcka, E. (2012). Psychologia twórczości [Psychology of creativity]. GWP, Gdansk.

10. OECD (2001). The Well-being of Nations. The Role of Human and Social Capital. Retrieved from: http://www. oecd.org/site/worldforum/33703702.pdf [Accessed 04.07.2018].

11. Podogrodzka, M. (2017). Kreatywność zasobów ludzkich w wybranych miastach Polski [The creativity of human resources in selected cities of Poland]. Studia Ekonomiczne. Zeszyty Naukowe Uniwersytetu Ekonomicznego w Katowicach, 324, pp. 69-77.

12. Raszkowski, A. (2014). Znaczenie kreatywności w rozwoju regionalnym [The importance of creativity in regional development]. Studia i Materiały. Miscellanea Oeconomicae. Wydział Zarządzania i Administracji
Uniwersytetu Jana Kochanowskiego w Kielcach, 3, pp. 161-175.

13. Raszkowski, A. (2016). Znaczenie organizacji pozarządowych w procesie kształtowania kreatywnego kapitału ludzkiego w małych miastach na przykładzie Szklarskiej Poręby [The importance of non-governmental organizations in the process of shaping creative human capital in small towns on the example of Szklarska Poręba]. Studia Ekonomiczne. Zeszyty Naukowe Uniwersytetu Ekonomicznego w Katowicach, 279, pp. 122-131.

14. Reid, B., Albert, A., Hopkins, L. (2010). A Creative Block? The Future of the UK. Creative Industries: A Knowledge Economy \& Creative Industries Report, Work foundation. Retrieved from: http://blueprintfiles. s3.amazonaws.com/1321209169-277_A-creativeblock.pdf [Accessed 04.07.2018].

15. Rindermann, H., Sailer, M., Thompson, J. (2009). The impact of smart fractions, cognitive ability of politicians and average competence of peoples on social development. Talent Development and Excellence, 1 (1), pp. 3-25.

16. Stec, M., Filip, P., Grzebyk, M., Pierścieniak, A. (2014). Socio-economic development in EU member states - concept and classification. Engineering Economics, 259 (5), pp. 504-512.

17. Szara, K. (2015). Uwarunkowania rozwoju w świetle koncepcji „3T” [Development factors in '3T' concept]. Optimum. Studia Ekonomiczne, 1 (73), p. 178-187.

18. Towse, R. (2011). Ekonomika kultury. Kompendium [Economics of culture. Compendium]. Narodowe Centrum Kultury, Warszawa.

19. UNCTAD (2008). Creative economy report 2008. The challenge of assesing the creative economy: towards informed policy-making. Geneva. Retrieved from: www. unctad.org/en/docs/ditc20082cer_en.pdf [Accessed 04.07.2018].

20. Urząd Statystyczny Rzeszów (2012). Ludność w województwie podkarpackim. Stan i struktura demograficzno-społeczna. Narodowy Spis Powszechny Ludności i Mieszkań 2011 [Population in the Podkarpackie Voivodeship. Demographic and social status and structure. National Population and Housing Census 2011]. Rzeszów.

21. Woźniak, M.G. (2005). Kapitał ludzki i intelektualny w strategii prowzrostowej ograniczającej nierówności społeczne [Human and intellectual capital in a pro-growth strategy limiting social inequalities]. Nierówności Społeczne a Wzrost Gospodarczy, 6, pp. 173-189. 